Makale Geliş | Received: 12.06 .2019

Makale Kabul | Accepted: 29.09.2019

DOI: $10.18795 /$ gumusmaviatlas. 576792

Mavi Atlas, 7(2)/2019: 1-27

Araştırma Makalesi | Research Article

\begin{abstract}
Ali Murat KIRIK
Doç. Dr. | Assoc. Prof. Dr. Marmara Üniversitesi, İletişim Fakültesi Radyo, Televizyon ve Sinema Bölümü, İstanbul-TÜRKIYYE Marmara University, Faculty of Journalism, Department of Radio, TV and Cinema, Istanbul-TURKEY

ORCID: 0000-0002-5771-4843 murat.kirik@marmara.edu.tr

Kenan BÖLÜKBAŞ

Öğr. Gör. Dr. | Lecturer Dr. TRT İstanbul Radyosu Müdürü, İstanbul-TÜRKIYYE Director of TRT Istanbul Radio, Istanbul-TURKEY ORCID: 0000-0001-2345-6789 bolukbaskenan@gmail.com
\end{abstract}

Gönül CENGIZZ

Dr. Öğr. Üyesi | Assist. Prof.Dr. Gaziantep Üniversitesi, Güzel Sanatlar Fakültesi Sinema ve Televizyon Bölümü, Gaziantep-TÜRKIYYE Gaziantep University, Faculty of Fine Arts Department of Cinema and Television, Gaziantep-TURKEY ORCID: 0000-0001-6685-5376 gonulcengiz88@gmail.com

\title{
Sosyal Medya Bağlamında Dijital Vatandaşlık: TRT İstanbul Radyosu Prodüktörleri Üzerinden Bir Değerlendirme
}

$\ddot{O} z$

İnternet ve teknolojinin toplumlar üzerinde yarattığı etki, geleneksel vatandaşlık olgusunu dijital ortama da taşımış ve bu durum, dijital vatandaşlık kavramını ortaya çıkarmıştır. Dijital vatandaşlık olgusu; düzenli, etkili internet erişimi ve bilişim okuryazarlığını zorunlu kılmaktadır.

$\mathrm{Bu}$ çalışma, günümüzün vazgeçilmez iletişim ve paylaşım araçlarından biri olan sosyal medyayı, dijital vatandaşlık bağlamında inceleyerek internet kullanıcılarının sorumluluklarına dikkat çekmiştir. Bu çalışmayla aynı zamanda, dijital vatandaşlığın doğru şekilde kullanılabilmesi amacıyla bireylere sağlanan eğitim olanakları da araştırılmıştır. Basit tesadüfi örnekleme olarak TRT İstanbul Radyosunda göreve yeni başlayan program yapımcıları yani prodüktörler (10 kişi) ile yapılan çalışmada, sosyal bilimlerde en sık kullanılan veri toplama yöntemlerinden biri olan görüşme tekniği kullanılmıştır. Prodüktörlere Ribble'in dijital vatandaşlık kavramını tanımlamakta kullandığı boyutlar çerçevesinde hazırlanmış on bir soru yöneltilmiştir.

Görüşmeler sonucunda katılımcılar dijital vatandaşlık konusunda yeteri kadar bilgiye sahip olmadıklarını ve bu alanda ülkemizde gerekli eğitimlerin verilmediğini vurgulamaktadır. Çalışmadan elde edilen bulgular, Ribble'in tanımladığı kavramın günlük yaşamın gerektirdiği vatandaşlık sorumlulukları ile dijital sorumluluklar arasında doğrudan bağlantısı olduğu sonucuna ulaşmakta ve sosyal medyanın tanımlanan bu sorumluluklar çerçevesinde kullanılmasının önemine dikkat çekmektedir.

Anahtar Kelimeler: Dijital Vatandaşlık, Sosyal Medya, Dijital Vatandaşlık Eğitimi, Dijital Vatandaşlık Boyutları. 


\title{
Ali Murat KIRIK, Kenan BÖLÜKBAȘ, Gönül CENGiz, "Sosyal Medya Bağlamında Dijital Vatandaşlk: TRT İstanbul Radyosu Prodüktörleri Üzerinden Bir Değerlendirme” Mavi Atlas, 7(2)/2019: 1-27
}

\section{Digital Citizenship in the Context of Social Media: Assessment of Negotiations with Producers on TRT Istanbul Radio}

\begin{abstract}
The impact of the Internet and technology on societies has led to the digital presence of traditional citizenship and the concept of digital citizenship has emerged. The phenomenon of digital citizenship necessitates regular, effective internet access and information literacy.

This study has drawn attention to the responsibilities of internet user by examining social media, one of today's indispensable communication and sharing tools, in the context of digital citizenship. At the same time, educational opportunities provided to individuals in order to use digital citizenship correctly have been investigated with this study. As a simple random sampling, the interview technique, which is one of the most frequently used data collection methods in social sciences, has been used in the study conducted with the program producers (10 people) who has started to work at TRT Istanbul Radio. 11 questions have been prepared for the producers within the dimensions defined by Ribble's concept of digital citizenship.

As a result of the interviews, participants emphasizes that they do not have enough knowledge about digital citizenship and that the necessary training is not given in this country. The findings of the study show that the dimensions that Ribble defines in the concept of digital citizenship have reached the conclusion and the individual must use the technology to meet the needs of the world in which he or she is socially, economically and politically using social media in the context of digital responsibilities.
\end{abstract}

Keywords: Digital Citizenship, Social Media, Digital Citizenship Education, Digital Citizenship Dimensions.

\section{Giriş}

Tüm alanlarda dijital teknolojilerin hızla yayılması ve uygulanması, insanlara sosyal ve kültürel bağlamda hem araç hem de amaç olarak büyük kolaylıklar ve imkânlar sunmaktadır. Günlük yaşantımızda gerçekleştirdiğimiz her türlü eylem, dijital araçgereçlerin kullanılmasıyla geleneksel boyutlarından ayrılarak dijitalleşmeye başlamıştır.

Reynolds ve Scott'a (2016) göre internetin icad, dijital teknolojilerin gelişmesi, küresel iş gücünün teknolojik olarak yeniden yönlendirilmesi, sosyal medyanın etkin hale gelmesi ve yaygınlaşması; çalıştığımız, yaşadığımız, iletişim kurduğumuz ortamları kökten değiştirmiştir. Sosyal medya, hayatımızın her alanına dokunmaktadır. İnsan hayatının giderek daha önemli bölümleri, günümüzde kısmen veya tamamen online olarak yaşanmaktadır. İnternet kullanımının yaygınlaşması, her türlü bilgiye kolaylıkla ve denetimsiz bir şekilde ulaşılmasını sağlamıştır. İnternet, iletişimi sağlayan ve destekleyen bir araçken; örneğin siber zorbalık, internet bağımlılığı, cinsel ve kültürel eşitsizliklere yol açan bir risk faktörü olarak karşımıza çıkmaktadır. Bu risklerden toplumun en fazla etkilenen kesimi olan gençlerin, internet ve sosyal medyayı aktif şekilde kullanmalarına rağmen yeterli dijital okuryazarlığa sahip olmadıkları 


\section{Ali Murat KIRIK, Kenan BÖLÜKBAŞ, Gönül CENGIZ, "Sosyal Medya Bağlamında Dijital Vatandaşlık: TRT İstanbul Radyosu Prodüktörleri Üzerinden Bir Değerlendirme" Mavi Atlas, 7(2)/2019: 1-27}

anlaşılmaktadır. Bu nedenle, dijital vatandaş olmanın gerektirdiği hak ve sorumluluklar, bireylerin dijital donanımlarının güçlü olmasını gerekli kılmaktadır.

Gençlerin internette geçirdiği zamanı dikkate alırsak, dijital vatandaşlık kavramının günümüzdeki önemi daha da artmaktadır. İnternetin bilinçsiz kullanımı, bireyler üzerinde olumsuz birtakım sosyal ve psikolojik etkilere sebep olmaktadır (Sakallı 2015: 56). Peker ve Eroğlu'na (2015) göre yeni iletişim teknolojileri bireylere kimliğini gizleyebilme firsatı sunmaktadır. Bireylerin bu teknolojiler vasitasıyla sanal ortamlarda sahte hesaplar açma, zararlı e-postalar gönderme, başkalarına hakaret etme gibi sakıncalı davranışlar sergiledikleri de görülmektedir. Dijital dünyadaki davranışlar dikkate alındığında, vatandaş, zararlı çevrim içi ortamlarda kişisel bilgi istismarının hedefi olabilmektedir.

Prensky’ye (2001) istinaden, dijital değişim süreci zarfında teknoloji kültürü ile yetişen yeni kuşağı “dijital yerliler” olarak tanımlamak gerekmektedir. Prensky, aynı zamanda dijital teknolojilere hâkim olanlar ile olmayanları "dijital yerliler (digital natives)" ve "dijital göçmenler (digital immigrants)" olarak ikiye ayırmıştır. Dijital yerliler, 1980 ve sonrasında doğan ve yeni teknolojilerle donanmış olan nesilden oluşmaktadır. Dijital göçmenler ise 1980 öncesi doğan, dijital teknolojilere yabancı olan, aynı zamanda uyum sağlamaya çalışan kuşağı oluşturmaktadır. Tanımsal farklılıkların buluştuğu ortak nokta ise teknolojinin bireyin hayatının içinde olma yoğunluğunun, bireyi dijital bir nesil üyesi yapmasıdır. Bu nedenlerdendir ki dijital göçmenlikten dijital nesle uzanan süreçte, teknolojinin hayatımızdaki yeri artmıştır (Sarsar 2017: 94).

Toplum ile teknolojinin çok hızlı etkileşimi, dijital ortamlarda sorumlulukların bilincine varılması, dijital vatandaşlık kavramının ortaya çıkmasına neden olmuştur. Özellikle sosyal medyanın dünya çapında yaygınlaşması, dünya vatandaşlarının eşit hak ve sorumluluklara sahip dijital vatandaşlar oldukları yönündeki tartışmalara neden olmuştur.

Bu araştırmanın amacı, “dijital vatandaşlık kavramı ve boyutlarını" sosyal medya bağlamında incelemek, bu inceleme kapsamında TRT İstanbul Radyosunda göreve yeni başlayan prodüktörlerin "dijital vatandaşlık kavramı ve boyutları" hakkındaki görüşlerini ortaya koymak, konuyla ilgili yeterli bilgi düzeyine sahip olup olmadıklarını araştırmaktır. $\mathrm{Bu}$ amaç doğrultusunda aşağıdaki soruya cevap aranmıştır:

Dijital vatandaşlık kavramının alt boyutlarından olan;

- Dijital erişim, 


\section{Ali Murat KIRIK, Kenan BÖLÜKBAŞ, Gönül CENGiZ, "Sosyal Medya Bağlamında Dijital Vatandaşlk: TRT İstanbul Radyosu Prodüktörleri Üzerinden Bir Değerlendirme” Mavi Atlas, 7(2)/2019: 1-27}

- Dijital ticaret,

- Dijital iletişim,

- Dijital okuryazarlık,

- Dijital etik,

- Dijital kanun,

- Dijital haklar ve sorumluluklar,

- Dijital sağlik,

- Dijital güvenlik kavramlarını, göreve yeni başlayan prodüktörler sosyal medya çerçevesinde nasıl kullanmaktadır?

Araştırma yöntemi olarak, olasılığa dayalı örnekleme türlerinden olan basit tesadüfi örnekleme kullanılarak, TRT İstanbul Radyosunda göreve yeni başlayan program yapımcıları yani prodüktörler (10 kişi) ile görüşme yapılmıştır. Prodüktörlere Ribble'in dijital vatandaşlık kavramında tanımladığ 1 boyutlar kapsamında hazırlanan 11 soru yöneltilmiştir.

Taylan (2015: 67), basit tesadüfi örneklemede birimlerin evreni yeterli düzeyde temsil etmesi için evrenin olabildiğince homojen olması gerektiğini vurgulamaktadır. Buna istinaden hem seçilen deneklerin meslekleri hem de deneklere yöneltilen sorular homojendir. Deneklerin benzeşik konumda olması ortalamayı etkilememektedir. Fakat seçilen deneklerin erkek ve kadın sayı oranı (6 erkek, 4 kadın) aynı değildir. Zaten Yıldırım ve Şimşek'in de vurguladıkları gibi, belirli özelliklerin tüm bireylerde eşit olarak dağıldığı benzeşik bir evreni bulmak zordur.

Veri toplama arac olarak görüşme yöntemi türlerinden biri olan standartlaştırılmış açık uçlu görüşme türünden faydalanılmıştır. Standartlaştırılmış açık uçlu görüşme, dikkatlice yazılmış ve belirli sıraya konmuş bir dizi sorudan oluşur ve her görüşülen bireye bu sorular aynı tarzda ve sırada sorulur (Görmez 2017: 55). Görüşmelerden elde edilen veriler, içerik analizi yöntemi kullanılarak çözümlenmiştir. Prodüktörlerle yapılan görüşmede alt problemler dikkate alındığında verilerden toplam 10 temaya ulaşılmıştır.

Araştırmanın çalışma grubu 2017 yılında göreve yeni başlayan 10 prodüktörden oluşmaktadir.

Çalışma, TRT İstanbul Radyosu'nda göreve yeni başlayan (2017 yılı) 10 prodüktör ve 11 adet soru ile sınırlandırılmıştır. 


\section{Ali Murat KIRIK, Kenan BÖLÜKBAŞ, Gönül CENGIZ, "Sosyal Medya Bağlamında Dijital Vatandaşlık: TRT İstanbul Radyosu Prodüktörleri Üzerinden Bir Değerlendirme” Mavi Atlas, 7(2)/2019: 1-27}

\section{Vatandaşlık Tanımı ve Dijital Vatandaşlık}

Dijital vatandaşlık kavramına geçmeden önce vatandaşlık tanımının yapılması gerekmektedir. Farklı bağlamlarda uygulanan birçok vatandaşlık tanımı vardır. Sosyologlar ve siyaset bilimcileri vatandaşlığı üç boyutta ele almaktadır (Dominique 2006).

- Medeni, siyasi ve sosyal haklarla tanımlanan yasal statü olarak vatandaşlık

- Siyasal iletişim ajansı olarak vatandaşlık ve siyasal kurumlara aktif katılım

- Farklı kimlik kaynağı olan politik bir topluluğun üyesi olarak vatandaşlık

İngiliz sosyolog T.H.Marshall (1992: 8), "sosyal mirasın tamamını paylaşma ve toplumda hâkim olan standartlara göre medeni bir varlığın hayatını yaşama hakkı" da dâhil olmak üzere vatandaşlığı belli bir siyasi topluluğun üyelerine, belirli sivil, siyasal ve sosyal haklar üyeliği olarak tanımlamıştır.

Vatandaşlık kavramı, aynı zamanda milliyet düşüncesiyle de bağlantılıdır. Birçok politik teori, vatandaşların bir tür ortak kültürel temele sahip olduğunu varsaymaktadır (Iija 2011: 8). Honohan'a (2002: 274-275) göre paylaşılan kültürel temel, bazı siyasi etnik ortaklıklar ya da daha derin kültürel bağlar yerine paylaşılan halk kültürüne dayanmaktadır.

Teknolojinin çok hızlı geliştiği dünyada, sahip olduğumuz vatandaşlık pratikleri değişerek küresel vatandaşlığa doğru evrilmektedir. Zamanının büyük kısmını sürekli internette geçiren bireyler, artık toplumdaki vatandaşlik görevleri ile beraber dijital dünyadaki vatandaşlık görevlerini ve sorumluluklarını da yerine getirmek zorundadır.

Dijital vatandaşlık, vatandaşlık sorumluluklarının gelişen ve değişen yeni teknolojiler ışığında yerine getirilmesi olarak da yorumlanabilmektedir. Çubukçu ve Bayzan (2013), dijital vatandaşlığ teknolojiyi yerinde ve yeterince kullanabilen, kişisel özgürlüklere zarar vermeyen ve etik davranışların farkında olan, paylaşımcı ve iş birlikçi kişiler olarak tanımlamaktadır.

Gleason ve Gilleren'in belirttiği gibi dijital vatandaşlık, politik katılımın öncüsüdür; çevrim içi bilgi ve hizmetlere daha fazla erişimin olması, politik katılımda da hep artış olacağını göstermektedir. Topluma çevrim içi katılım, dijital medyanın yeterliliğini, özellikle de mevcut ve yeni teknolojileri kullanarak medyayı üretme, iş birliği yapma, paylaşma ve eleştirme yeteneği gerektirmektedir (2018: 205). Ağa bağlı 


\section{Ali Murat KIRIK, Kenan BÖLÜKBAŞ, Gönül CENGIZ, "Sosyal Medya Bağlamında Dijital Vatandaşlık: TRT İstanbul Radyosu Prodüktörleri Üzerinden Bir Değerlendirme" Mavi Atlas, 7(2)/2019: 1-27}

teknolojilerin ve değişen sosyal, politik, kültürel ve ekonomik yapıların ve uygulamaların sonucu olarak, gençler yeni vatandaşl1k biçimleri geliştirmişlerdir.

Ribble (2011) dijital vatandaşlık kavramını açıklarken bu kavramı dokuz boyutta ele almaktadir.

\section{Dijital Erişim: Toplumun Tamamının Elektronik Katılımı}

Kullanıcılar, teknoloji konusunda herkesin aynı firsatlara sahip olmadığının farkında olmalıdır. Eşit dijital hakları sağlamak ve elektronik erişimi desteklemek dijital vatandaşlığın çıkış noktasıdır. Dijital haklarımızı kısaca özetlemek gerekirse, bireylerin çevrim içi ortamda bilgiye erişme, içerik oluşturma ve bu içeriği yayma haklarını ifade etmektedir. Bu durumda dijital dışlama, teknolojik araçları giderek çok fazla kullanan bir toplumda, teknolojiden uzak bireylerin barınmasını zorlaştırmaktadır. Teknolojiye erişim sağlamaya ve onu yaygınlaştırmaya yardımcı olmak, tüm dijital vatandaşların hedefi olmalidir.

Ribble'in dijital erişim kavramına ek olarak, Yayla da (2017: 1) bilgiye erişimin çok daha kolay ve ucuz hale gelmesiyle bilgi dolaşımının hızlandığını ve dijital erişim yöntemlerinin çeşitlenmesiyle bilgide sınırlılık ve bilgiyi saklama imkânının ortadan kalktığını vurgulamaktadır.

\section{Dijital Ticaret: Elektronik Eşya Alım Satımı}

Teknoloji kullanıcıları, pazar ekonomisinin büyük bir kısmını elektronik ortamda yapmaktadır. Dijital ortamlarda gerçekleşen yasal alışverişlerde alıcı veya satıcı oluşabilecek sorunların farkında olmalıdır. Özellikle oyuncak, giyim, araba, yemek vesaireler internet satın alımlarının bireyler için genel kullanılabilirliğini de yaygınlaştırmıştır. Aynı zamanda bazı ülkelerin yasaları veya ahlakı ile çelişen mallar ve hizmetler (yasadışı indirme, pornografi ve kumar oyunları) ortaya çıkmaktadır. Bunların sonucu olarak da internet kullanıcılarının dijital ekonomide nasıl etkili tüketiciler olabileceklerini öğrenmeleri gerekmektedir.

Zaman ve mekân kavramı olmaksızın dijital vatandaş istediği yerden internete bağlanarak her yerden alışveriş yapabilme olanağına sahiptir (http://www.selcuk.edu.tr/dosyalar/files/074/elektronik_ticaret(1).pdf: 19).

\section{Dijital İletişim: Elektronik Bilgi Alışverişi}

Dijital devrimdeki önemli değişikliklerden biri, insanların birbiriyle iletişim kurma yeteneğidir. 19. ve 20. yüzyıldaki sınırlı iletişim biçimleri, 21. yüzyılda iletişim 


\section{Ali Murat KIRIK, Kenan BÖLÜKBAŞ, Gönül CENGIZ, "Sosyal Medya Bağlamında Dijital Vatandaşlık: TRT İstanbul Radyosu Prodüktörleri Üzerinden Bir Değerlendirme" Mavi Atlas, 7(2)/2019: 1-27}

seçeneklerinin (ör: e-posta, cep telefonları, anlık mesajlaşma) çok hızlı çoğalmasıyla haberleşme alanında önemli bir yer edinmiştir. Artık herkes, her yerden ve her zaman istediği kişiyle iletişime geçme firsatına sahiptir.

Öztürk (2013), dijital iletişim olanaklarının gelişimi, bilgiyi tükettiğimiz kadar üretmemize de olanak sağladığının altını çizmektedir. Özellikle sosyal medya kullanımı konusunda yaşanan gelişmeler, iletişim konusunda bir önceki döneme göre büyük miktarlarda bilginin üretilmesine ve tüketilmesine, kullanıcılar arasında etkileşim kurulmasına imkân sunmaktadır.

Tüm bu geniş seçeneklere rağmen ne yazık ki pek çok kullanıcı, farklı dijital iletişim biçimleriyle karşı karşıya kaldığında, uygun kararların nasıl verileceği konusunda eğitilmemiştir. O yüzden dijital vatandaşlık eğitimi sadece yetişkinlere değil, aynı zamanda gençlere ve çocuklara da verilmelidir.

\section{Dijital Okuryazarlık: Teknoloji ve Kullanımı Hakkında Öğretim ve Öğrenme Süreci}

Yeni teknolojilerin öğretilmesinin yanı sıra onların nasıl kullanılması gerektiğine de odaklanılmalıdır. Örneğin, askerî personel ve tıp mensuplar, dijital teknolojileri hem doğru hem de verimli kullanmada oldukça başarılı bulunan çalışanlardır. Bu da onların toplumda bilinçli dijital vatandaşlar olarak nitelendirilmesini sağlamaktadır. Dijital vatandaşlık, insanları yeni bir şekilde eğitmeyi amaçlamakta ve bu vatandaşların yüksek düzeyde dijital medya okuryazarlığı becerilerinin oluşmasına ihtiyaç duymaktadır.

Gürcan’a (2013) göre dijital okuryazarlık “Anlama, bilgisayarlar yoluyla sunulan geniş ölçekteki çoklu-formattaki enformasyonu kullanabilme yetisidir." Öğrencilerin dijital araçların belirli özelliklerini anlamalarının önemine dikkat çekmektedir, aynı zaman da öğrencilerin okul müfredatının bir parçası olarak oluşturulmuş bu araçları uygun bir biçimde nasıl kullanılacağını keşfetmek için uygun firsat olduğuna dikkat çekmektedir.

\section{Dijital Etik Kuralları: Elektronik Davranış Kuralları veya Yönetimi}

Teknoloji kullanıcıları, bu faktörü dijital vatandaşlık konusunda çok sık karşılaşılan sorunlardan biri olarak görmektedir. Başka bir deyişle, dijital görgü kurallarının internette fazla zaman geçiren ve sosyal medyayı aktif kullanan kişilere öğretilmesinde yarar vardır. Fakat bazen bu kurallar düzenleyici olmak yerine yasaklayıcı özelliğe sahip olarak, dijital vatandaşların görgü kurallarının dışına çıkmasına da 


\section{Ali Murat KIRIK, Kenan BÖLÜKBAŞ, Gönül CENGIZ, "Sosyal Medya Bağlamında Dijital Vatandaşlık: TRT İstanbul Radyosu Prodüktörleri Üzerinden Bir Değerlendirme" Mavi Atlas, 7(2)/2019: 1-27}

sebebiyet vermektedir. Dolayısıyla dijital etik kuralları düzenlerken birçok dengeyi gözetmek gerekmektedir.

Fiziksel dünyadaki etik anlayışının dijital etik anlayışından farklı olan bir tarafı da, fiziksel ortamda eğitimciler etik ve davranışlar konusunda öğrenciyi yönlendirme firsatı bulmaktadırlar. Dijital ortamdaki etkileşimin çoğu kişiye özeldir ve mobil cihazlarla verilir (Görmez 2017: 7).

\section{Dijital Hukuk: Eylemler ve Resmi İşler İçin Elektronik Sorumluluk}

Dijital hukuk, toplumdaki teknolojik etik konusunu ele almaktadır. Etik olmayan kullanım, hırsızlık veya suç şeklinde kendini göstermektedir. Dijital kullanıcıların diğer insanların çalışmalarını, kimliklerini veya mülklerini, çevrim içi ortamda çalmanın ya da bunlara zarar vermenin bir suç olduğunun farkında olması gerekmektedir. Kullanıcıların, etik değerlere önem veren bir toplumda, farkında olmaları gereken bazı sosyal kurallar vardır. Bu kurallar, internette işlerini yürüten veya sadece çevrim içi oyun oynayan herkes için geçerlidir. Örneğin, başkalarına bilgi sızdırma, yasa dışı müzik indirme, intihal, spam gönderme veya insanların kimliğini veya mülkünü çalmak vb. dijital etik açısından uygun değildir. Bu konu, dijital vatandaş sorumlulukları olarak dikkat edilmesi gereken önemli bir unsurdur. Özellikle internette akademik olarak yapılan intihaller veya sahte kimlikle açılmış sosyal medya hesapları oldukça fazladır. Hatta bilinçli dijital vatandaşların bir kısmı da kendi çıkarları için bu yasal olmayan durumdan faydalanabilmektedir.

\section{Dijital Haklar ve Sorumluluklar: Dijital Dünyadaki Herkes İçin Var Olan Geniş Özgürlükler}

Birçok dünya ülkesinin anayasasında olduğu gibi, her dijital vatandaşa yönelik temel haklar dizisi vardır. Dijital vatandaşların mahremiyet, özgür konuşma vb. hakları mevcuttur. Temel dijital haklar dijital dünyada ele alınmalı, tartışılmalı ve anlaşılmalıdır. Doğal olarak bu haklar beraberinde sorumluluklar da getirmektedir. Keser, Semerci ve Çetinkaya (2018: 275), gerçek dünyada olduğu gibi dijital dünyada da hak ve özgürlüklerin sınırsız olmadığını vurgulamaktadır. Diğer yandan dijital dünya sınırlarının olmamasının, dijital vatandaşlar için ulusal düzenlemelerin yanında uluslararası bazı düzenlemeleri, uyulması gereken etik kuralları beraberinde getirdiğinin de altı çizilmektedir.

Hem internet hem de sosyal medya kullanıcıları, teknolojinin uygun bir şekilde kullanımını tanımlamaya çalışmalıdır. Çünkü modern toplumlarda hak ve sorumlulukları yerine getiren dijital vatandaşlara ihtiyaç duyulmaktadır. 


\section{Ali Murat KIRIK, Kenan BÖLÜKBAŞ, Gönül CENGİ, "Sosyal Medya Bağlamında Dijital}

Vatandaşlık: TRT İstanbul Radyosu Prodüktörleri Üzerinden Bir Değerlendirme”

Mavi Atlas, 7(2)/2019: 1-27

\section{Dijital Sağlık: Dijital Dünyada Fiziksel ve Psikolojik Durum}

Göz güvenliği, tekrarlayan stres sendromu ve sağlam ergonomik uygulamalar, yeni teknolojik dünyada ele alınması gereken önemli konulardır. Fakat fiziksel sağlığın ötesinde, internet bağımlılığı gibi yaygın hâle gelen psikolojik sıkıntılar, dikkate alınması gereken sorunların başında gelmektedir.

Doğanyiğit (2015: 101), dijital sağlık uygulamalarının, hızlı erişim teknolojisi sayesinde, her an her yerde kullanılabildiğinin de önemini belirtmektedir.

Dijital vatandaşlara, teknolojinin faydalarının yanı sıra tehlikelerinin de öğretilmesi gerekmektedir. Bu bağlamda dijital vatandaşlık, teknoloji kullanıcılarının eğitim ve öğretim yoluyla kendilerini nasıl koruyacaklarının öğretildiği bir kültürü de içermektedir.

\section{Dijital Güvenlik (Kendini Koruma): Güvenliği Garanti Altına Almak İçin Elektronik Önlemler}

Her toplumda yeni yetişen kuşaklara örnek olacak rol modeller bulunmayabilir. Çünkü bireylerin kendi güvenliği için toplumdaki diğer üyelere güvenmesi tek başına yeterli değildir. Örneğin, kendi evimizde güvenliğimiz için kapılarımızı kilitlemekte ya da evlerimize yangın alarmları koymaktayız. Dijital güvenlik için de benzer önlemlerin geçerli olması gerekmektedir. Virüs koruma programlarına, verilerin yedeklenmesine ve teknolojik aygıtların sık sık kontrol edilmesine ihtiyaç duyulmaktadır. Çok az kullanılan elektronik postalar, unutulmuş şifreler, açık bırakılmış sosyal medya ve e-posta hesapları, dijital dünya içinde yer alan kötü niyetli kullanıcılar tarafından takip edilmektedir. Bu kişiler, açık yakaladıkları an eyleme geçerek her türlü dijital hukuksuzluğu yapma potansiyeline sahiptir. Sorumluluk sahibi dijital vatandaşlar, bilgilerin çalınmasına ve kişilerin zarar görmesine neden olabilecek kötü niyetli kullanıcılardan korunmayı bir görev olarak görmelidir.

Günümüzde teknolojik gelişmeler artık hayatın ayrılmaz bir parçası olmuştur. Kullanımı her geçen gün artan internet teknolojisinin en önemli yönlerinden biri de güvenlik ve gizlilik boyutudur. Ribble, bu öneminden dolayı dijital güvenliğin, dijital vatandaşlı̆̆ın dokuz boyutundan biri olduğunu öne sürmektedir.

Sosyal medya mecralarında kullanıcılar; bilgilerini, beğenilerini, görsellerini, videolarını, yorumlarını, takip ettiği sayfaları ve kişileri çoğu zaman takipçileri ile paylaşmaktadır. Tüm bu parametreler, bir anlamda kişinin fotoğrafını ve düşüncelerini çizmektedir. Bugün, bir kişinin sosyal medya mecralarında beğendiği bir sayfadan, bir 


\section{Ali Murat KIRIK, Kenan BÖLÜKBAŞ, Gönül CENGIZ, "Sosyal Medya Bağlamında Dijital Vatandaşlık: TRT İstanbul Radyosu Prodüktörleri Üzerinden Bir Değerlendirme" Mavi Atlas, 7(2)/2019: 1-27}

görsel ya da videodan nasıl bir düşünce yapısında olduğu artık anlaşılabilmekte ya da en azından o kişinin dünya görüşü hakkında bir fikir yürütülebilmektedir. Yani sosyal mecralar, kişileri bir kimliğe büründürmekte ve "uygulamaları" ile de bu kimliği gözler önüne sermektedir.

Bilindiği gibi sosyal medyanın öncülerinden ve en aktif kullanılan mecralarından biri Facebook’tur. Facebook; bünyesinde yorum, beğeni, paylaşılanı paylaşma gibi farklı alt uygulamalar bulundurmaktadır. Örneğin "beğen" butonunun, kullanıcıların toplum içinde yer edinme, sevilme gibi duygularını tatmin ettiği ve "yaşanılan değil hayal edilen" algısını oluşturduğu iddia edilmektedir.

Günümüzde, sosyal medyanın kişide oluşturduğu dönüşümün yanında, yukarıda değinilen alt uygulamaları, kendilerine çıkar sağlamak amaçlı kullanan şirketlerin var olduğundan da söz edilmektedir. Yakın zamanda ortaya çıkan ve kamuoyunda da tartışmalara neden olan, İngiliz analiz şirketi Cambridge Analytica'nın Facebook için geliştirdiği bir uygulama üzerinden milyonlarca Facebook kullanıcısının verilerini izinsiz bir şekilde elde ettiğinin ortaya çıktığı Facebook'taki veri skandalı, bu bilgiyi doğrulamaktadır. Şirketin, 2016 ABD Başkanlık Seçimleri'nde Donald Trump'ın kampanyası için çalıştığı ve bu yolla elde ettiği bilgileri seçmenlerin siyasi tercihlerini manipüle etmekte kullandığı anlaşılmıştır(https://www.bbc.com/turkce/haberler-dunya43469094, 2018).

Bireylerin sosyal medyadaki davranışlarını çözümlemek amacıyla yola çıkan şirket, 2014 yılında teorilerini test etmek için "My Personality" isminde bir Facebook uygulaması oluşturmuştur. Facebook ise "daha fazla kullanıcıya ulaşmak, daha fazla para kazanmak amacıyla" mevcut kullanıcılarını bir nevi satışa çıkarmıştır. Bu yolla, uygulamayı kullanan kullanıcılar ve o kullanıcıların arkadaşları olmak üzere zincirleme bir veri deposu oluşturulmuştur. Uygulamayı kullanan ve böyle bir uygulamanın varlığından bile haberdar olmayan Facebook kullanıcıları, özellikle "beğen" butonu ile farkında olmadan kendilerini ele vermektedir. Kullanıcı profillerinden oluşturulan kişilik testlerinin sonuçları; projelerde, devletlerin seçim kampanyalarında kullanılmak üzere saklanmakta ve bu bilgileri talep eden kuruluşlara satılmaktadır (https://www.bbc.com/turkce/haberler-dunya-43469094 2018). Kişiyi kendisinden bile daha iyi tanıdığı düşünülen bu yöntem sayesinde, birçok ülkedeki siyasetçinin seçimlerde başarı sağlamaya çalıştığı düşünülmektedir.

Bu noktada sorulması gereken şey, Facebook'un ve sosyal medya mecralarının güvenlik ve gizlilik politikalarıdır. Artık yaşamlarında teknolojiyi vazgeçilmez hale 


\section{Ali Murat KIRIK, Kenan BÖLÜKBAŞ, Gönül CENGIZ, "Sosyal Medya Bağlamında Dijital Vatandaşlık: TRT İstanbul Radyosu Prodüktörleri Üzerinden Bir Değerlendirme” Mavi Atlas, 7(2)/2019: 1-27}

getiren dijital vatandaşların, bireysel olarak sağladığı "güvenlik ve gizlilik" önlemlerinin esasında çok da etkili olmadığı, ortaya çıkan bu olaylar zinciri ile ispatlanmıştır.

Her toplumun kendine özgü kültürü, yaşam biçimi, hayatı algılayış şekli vardır. Toplumların sosyolojik ve kültürel göstergelerinin yanı sıra bu durum, bireyler arasında da farklılık göstermektedir. Mahremiyet, gizlilik, ahlaki değerler vb. bazı parametreler, toplumsal ya da bireysel bağlamda değişmez. Bu kavramlar, tüm toplumlarda ve bireylerde genel geçer olgular arasında bulunmaktadır. Facebook veri skandalı, bazı sosyal medya şirketlerinin, sadece kendi kazançları için etik olmayan yollar izleyebildiğini, kullanıcılarını "ürün” gibi görebildiğini ve etrafımızı saran dijital dünyanın esasında çok da güvenilir olmadığını göstermiştir. Aynı şekilde bireylerin mahremiyetinin ve özel yaşantılarının gizliliğinin korunmadığında da nelere yol açtığı bu “olay” la ortaya çıkmıştır.

Dijital dünyada bu uygulamaları kullanmamak ya da sosyal mecralardan uzak durmak çözüm değildir. Teknolojinin bu denli hayatın içinde olduğu ve toplumların gelişmişlik seviyesini yansıtan öğe olması bu durumu özellikle de dijital vatandaşlar için artık imkânsız kılmaktadır. Bu olay, dijital güvenliğin günümüz dijital vatandaşları için çok önemli olduğu gerçeğini açıkça göstermektedir. $\mathrm{Bu}$ açıdan sosyal medya mecralarında kişisel verilerin gizliliğini sağlamak, özel verilerin kötüye kullanılmasını önlemek, hem sosyal medya şirketlerinin hem devletin hem de dijital vatandaşlar olarak tanımlanan bireylerin görevidir. Örneğin, gizlilik ve güvenliği sağlamak adına, herhangi bir online platformun kullanıcıları, talep edilse dahi bütün kimlik bilgilerini gözler önüne sermemelidir. Facebook benzeri platformlar, veri koruma standartlarında düzeltmeler yapmalı ve kullanıcıların arkadaşlarının hesaplarına ulaşmayı zorlaştıran bazı kurallar koymalıdır.

Bu olay, günümüzde dijital vatandaşların kişisel bilgilerinin korunması ve özel hayatlarına saygı konusunda ciddi endişeye neden olmuş ve Facebook gibi sosyal medya platformlarının yalan haber ve seçimlerin yönlendirilmesi gibi konularda kişisel bilgilerin siyasi ve ticari hedeflerle yasa dışı kullanımına karşı ciddi önlemler alınmasının önemini göstermiştir. Bir başka önemli nokta da, özel olarak birkaç kişinin verileri ile anlamlı bir sonuca ulaşılamasa da milyonlarca veriye ulaşılıp belli bir amaca göre değerlendirilirse, kitlesel bir enformasyon silahına dönüştürülebileceğini göstermektedir.

Benzer nedenlerle ülkemizde, 2016 y1lında "6698 sayılı Kişisel Verilerin Korunması Kanunu" yürürlüğe girmiştir. Kanunun amac1; kişisel verilerin işlenmesinde, başta özel hayatın gizliliği olmak üzere, kişilerin temel hak ve özgürlüklerini korumak ve 


\section{Ali Murat KIRIK, Kenan BÖLÜKBAŞ, Gönül CENGIZ, "Sosyal Medya Bağlamında Dijital Vatandaşlık: TRT İstanbul Radyosu Prodüktörleri Üzerinden Bir Değerlendirme" Mavi Atlas, 7(2)/2019: 1-27}

kişisel verileri işleyen gerçek ve tüzel kişilerin yükümlülükleri ile uyacakları usul ve esasları düzenlemektir.

Özetlemek gerekirse; dijital vatandaş, dijital dünyada iletişim kurma becerisine sahip, internet üzerinden alışveriş yapabilen, içerik üretebilen ve en önemlisi dijital dünyadaki hak ve sorumluluklarının farkında olan ve buna uygun davranışlar geliştirebilen kişi olarak tanımlanabilir. Ülkemiz açısından bakarsak, e-devlet uygulamalarını kullanabilen her birey, bir dijital vatandaş olarak görülebilir.

\section{Dijital Vatandaşlık Eğitimi}

Bilgi ve iletişim teknolojilerinin hızlı gelişmesiyle çevrim içi ve çevrim dışı arasındaki sınırların bulanıklaştığı dijital çağda, vatandaşlığın kavramsal kapsamı artık geleneksel olanla sınırlı kalmamalıdır. Minjeong ve Dongyeon'un vurguladığı gibi, dijital vatandaşlığın ortaya çıkması ile uyumlu olarak, okul-sınıf ortamındaki değisşiklikler; dijital cihazların kullanımı, internet ve dijital ders kitapları, akıllı eğitimin ve çevrim içi derslerin aktifleştirilmesi küresel bir trend haline gelmiştir (2018: 160). Bu anlamda Jones ve Mitchell'in (2015) vurguladığı gibi, gençlere yönelik dijital vatandaşlık eğitimi, basit düzeyde dijital okuryazarlık eğitiminden ve siber zorbalıkları önleme yönteminden farklı olmalıdır. Gençlerin, dijital dünyadaki vatandaşlıklarını geliştirmeleri için öğretmenlerin teknolojik eğitim derecesini de belirlemede net kriterlerin oluşturulması gerekmektedir. Fakat dijital vatandaşlık eğitimi, sadece dijital araçların kullanımını öğretmekle kısıtlı kalmamalı, bunun yanı sıra öğrenciyi çeşitli yönlerden dünyaya hazırlamak da bu eğitimin bir parçası olmalıdır. Eğitim, demokrasiyi ve ekonomik büyümeyi desteklediği gibi, internet de toplumun bir bütün olarak her şeyden yararlanma potansiyeline sahiptir ve bireylerin topluma katılımını kolaylaştırmaktadır.

Teknolojinin toplumsal yaşamı kolaylaştırmadaki rolüyle birlikte, eğitim-öğretim ortamlarında iletişimi kolaylaştırıcı ve ilerletici özelliğiyle önemli bir konuma sahip olduğu belirtilmektedir. Eğitim-öğretim sürecinde, derslerde dokümanların web ortamlarında paylaşılması, öğrencilerin araştırmalarını internet üzerinden yapması, uzaktan eğitim veren fakültelerin sınavlarını dahi dijital ortamlarda yürütmesi, teknolojinin süreçte sağladığı kolaylıklara olumlu örnekler teşkil etmektedir (Kocadağ 2012: 5).

Dijital vatandaş olarak tanımlanan bireylerin, temel bilgi teknolojilerinin kullanımına ilişkin yeterliliklere sahip olmalarıyla birlikte, teknolojinin kullanımına ilişkin bazı davranış normlarını benimsemeli ve bu konuda diğerlerine de rol-model 


\section{Ali Murat KIRIK, Kenan BÖLÜKBAŞ, Gönül CENGIZ, "Sosyal Medya Bağlamında Dijital Vatandaşlık: TRT İstanbul Radyosu Prodüktörleri Üzerinden Bir Değerlendirme" Mavi Atlas, 7(2)/2019: 1-27}

olmaları beklenmektedir. Bu davranış kuralları, bireylere planlı süreçlerle, eğitim yoluyla kazandirılmalıdır.

Reynolds ve Scott'a (2016) göre dijital vatandaşl1k eğitimi, çevrim içi güvenliği öğretmekle beraber, toplum üyelerine yetenekli dijital vatandaşlar olmaları için gereken becerileri ve eğilimleri sağlamaktadır. Bu kavram, çevrim içi ortamlarda daha aktif ve bilgilendirilmiş vatandaşları geliştirmeyi amaçlamaktadır. Örneğin, çevrim içi olarak olumsuz durumlara olumlu müdahale etme, çevrim içi bilgileri eleştirel olarak kullanma, çevrim içi sosyal ve politik tartışmaları olumlu bir şekilde karşılama gibi bir sürü çevrim içi durumları kapsamaktadır.

Bugün gençliğin sosyal boyutu, önceki nesillerinkinden önemli ölçüde farklıdır. Çünkü dijital medya teknolojisi, gençlerin cep telefonlarıyla sosyal ağ sitelerinde, anlık mesajlaşma platformlarında, kişisel bloglarında, sanal dünyalarda ve video paylaşım sitelerinde kimliklerini ifade etmeleri ve keşfetmeleri için yeni bir ortam yaratmaktadır. Minjeong ve Dongyeon'un (2018: 161) belirttiği gibi, bugünün gençleri, internet çağında dünyaya geldikleri için elektronik aygıtların eksikliğini hayal bile edememekteler. Dahası dijital ortamda büyüdüklerinden, hayatlarını dijital bir yerli olarak yönetmekteler. Dijital vatandaşl1k eğitiminin en önemli parçası, bilgisayar ve internet tabanlı teknik becerilerden oluşan dijital okuryazarlığın öğretilmesidir.

Dijital vatandaşlıkları sosyal medya anlayışlarına dayanan gençler, dijital ortamlarda kamu hedefleri için sosyal konularda görüşler sunmakta ve başkalarının statülerine göre hareket etmektedir. Dijital vatandaşlık eğitiminin hedefleri, gençlere sosyal medyanın nasıl çalıştığını anlamak için ihtiyaç duydukları bilgileri vermekten öteye geçmelidir. Dijital vatandaşlık duygusu geliştirilirken, gençlere, sosyal medyanın sadece kullanışlı bir araç olmadığının, aynı zamanda yaşadıkları dijital bir alan olduğunun vurgulanmasi gerekmektedir.

Her ne kadar dijital vatandaşlık kavramı internetin gelişimi ile paralel şekillense de, dijital vatandaşlık eğitimi, geleneksel vatandaşlık kavramlarının bir devamı niteliğinde anlaşılmalıdır. Çünkü dijital vatandaşlık kavramı, sosyal etik, okuryazarlık yeteneği ve rasyonel yargı yoluyla katılım gibi geleneksel vatandaşlık kavramlarının çeşitli özelliklerini içermektedir (Reynolds ve Scott 2016).

Dijital cihazların ve dijital bilginin en aktif kullanıcısı olan gençlerin eğitimine sadece okullar bazında değil, aynı zamanda tüm toplumsal alanlarda da önem verilmelidir. Toplumun geleceği; gençliğin, dijitalleşmenin olumlu etkilerini en üst 


\section{Ali Murat KIRIK, Kenan BÖLÜKBAŞ, Gönül CENGIZ, "Sosyal Medya Bağlamında Dijital Vatandaşlık: TRT İstanbul Radyosu Prodüktörleri Üzerinden Bir Değerlendirme” Mavi Atlas, 7(2)/2019: 1-27}

düzeye çıkararak ve olumsuz etkileri en aza indirerek, değişen sosyal gerçeklikle ne kadar etkili bir şekilde baş edebilmesine bağlı olacaktır.

\section{Sosyal Medya - Dijital Vatandaşılı İlişsisi}

Teknolojinin baş döndürücü bir hızla geliştiği ve bugün yeni olanın yarın kolaylıkla eski konumuna gelebildiği günümüz konjonktüründe, (Polat 2016: 416) gelişen her teknolojik bulgu bir öncekinin yerini almaktadır. Ve bu değişim sürecinde "eski” ya da "klasik" olarak nitelendirilen bulgulardan beslenilmektedir. Bu döngü, medya alanında da kendisini göstermiş ve "geleneksel medya" kavramı yerini "dijital medya" ya da "yeni medya" olarak isimlendireceğimiz bir alana bırakmıştır.

Geleneksel medyanın tek yönlü iletime ve dolayısıyla pasif alıcı kitlesine sahip oluşu, monolog yapısı, dikey (hiyerarşik) bir yapılanmada oluşu, dijital çağa doğan yeni nesil için bağlayıcı olamamıştır. Ve bu durumda geleneksel medya, özellikle dijital göçmen kuşakta bağımlılık, alışkanlık ve eskiye olan güven duygusu şeklinde karşılığını bulmuş ve öteye geçememiştir. Buna karşılık dijital medyanın çok yönlü iletime, aktif bir alıcı kitlesine ve yatay yapılanmaya sahip olması, çoğulcu ve daha demokratik bir katılıma dönük yapısı, özellikle dijital yerliler için bulunmaz bir nimet olmuştur.

Günümüzde çok sık karşımıza çıkan terimlerden biri de dijital medyanın uygulama alanı olan "sosyal medya"dır. Bu nedenle sosyal medya - dijital vatandaşlık ilişkisini değerlendirmeden önce sosyal medyanın bir tanımını yapmak yerinde olacaktır.

Kirtiş ve Karahan'a göre sosyal medya; en basit ifadeyle internet kullanıcılarının birbirleriyle çevrim içi iletişim kurmalarına olanak veren, içerik paylaşımı ve kişisel yorumlar gibi aktivitelere dayalı sosyal ağ siteleri olarak tanımlanabilir (2011). Sosyal medya, internet tabanlı olarak bireyleri farklı bireylerle sanal uzamda buluşturan web tabanlı hizmetler şeklinde değerlendirilebilir (Toprak vd. 2009: 28-29).

Bir diğer tanıma göre ise sosyal medya; kullanıcılara enformasyon, düşünce, ilgi ve bilgi paylaşım imkânı tanıyarak karşılıklı etkileşim yaratan çevrim içi araçlar ve web siteleri için ortak kullanılan bir terimdir (Sayımer 2009).

Sosyal medyanın gelişen iletişim sistemleri (küresel-yerel) ile birlikte yeniden tanımlandığını ve iletişim kurallarının tamamen yeniden değerlendirilmesi gerektiğini söyleyebiliriz. Özellikle sosyal medya ortamında yaptığımız her eylemin bir iz bıraktığı ve dolayısıyla kaydedildiği ve atacağımız her adımda dikkatli olunması gerektiği ve bu yeni zeminin şartlarına uygun bir şekilde olması gerektiği açıktır. Bu nedenle, sosyal medyada dijital bir içerik üretirken, paylaşırken bu ortamın yeni kurallarını, 


\section{Ali Murat KIRIK, Kenan BÖLÜKBAŞ, Gönül CENGIZ, "Sosyal Medya Bağlamında Dijital Vatandaşlık: TRT İstanbul Radyosu Prodüktörleri Üzerinden Bir Değerlendirme" Mavi Atlas, 7(2)/2019: 1-27}

kullanıcılarını ve taraflarını iyi değerlendirmek gerekir. Çünkü her bir sosyal medya kullanıcısı, sadece yaşadığı ülkenin vatandaşı değil, aynı zamanda coğrafi sınırların anlamsızlaştığı hatta ortadan kalktığı dijital dünyanın bir vatandaşı olarak görülmektedir.

Dijital medyanın, kullanıcıların iletişim çeşitliliğini ve iletişiminin üzerindeki hâkimiyetlerini önemli ölçüde artırmasının yanı sıra, dijital medya araçları vatandaşın denetleme vasıtalarından biri haline dönüşmüştür. Elektronik posta ile başlayan süreç özellikle Twitter gibi ortamlarla geleneksel, siyasal ve ekonomik algılarda önemli kırılmaların yaşanmasını sağlamıştır. Öyle ki artık "tabandaki küçük klavye darbeleri, tavandaki büyük isimleri tedirgin etmeye yetmektedir.” (Engin 2011: 35). Oluşan bu çok sesli yapı ve hızlı yayılım karşısında devletlerin de birtakım önlemler alma ve olası kötü niyetli yapılanmalar karşısında yaptırıma gitme durumunu açığa çıkarmıştır. Fakat sosyal medya platformları üzerindeki hükümet baskıları, internet içerikleri konusunda etkili olsa da bunu sansüre tabi tutmak hiç de kolay değildir. Çünkü sansürün hem teknolojik olarak uygulanması zor hem de etkisi asgari düzeydedir. Twitter, Facebook ve Google gibi şirketler, çevrim içi içeriği düzenlemeye yönelik faaliyetlerini hükümetlerle iş birliği içerisinde yapıyor gözükseler de bu iş birlikleri, her ülke hükümetiyle aynı oranda gerçekleşmemektedir. Bununla beraber benzer diğer bazı şirketler, bu iş birliğinden tamamen ya da kısmen kaçınmaktadır. Dolayısıyla sosyal medyanın toplumda politik, sosyal ve kültürel alanlarda oynadığı önemli rol düşünüldüğünde, dijital vatandaşlığın öneminin daha da arttığı söylenmektedir.

Sosyal medya, aynı zamanda kimliğin oluşumu, keşfi ve ifadesinde önemli bir rol oynayabilmektedir. Çünkü kimlik gelişimi ve dijital vatandaşlığın gelişimi arasında kuvvetli bir bağ vardır. Örneğin, gençler toplumu organize etmek için mikroblog ve sosyal paylaşım sitesi olan Twitter'ı kullandıkça, takip eden bir sosyal protesto etrafında takipçileri seferber edebilmekte ve sosyal protesto hareketlerini gerçek zamanlı gerçekleştirebilmekte ve böylece Twitter okuryazarlığını geliştirebilmekteler (Greenhow ve Gleason 2012). Bu okuryazarlık, Twitter'a nasıl ve ne zaman katılacağına dair bilinçli kararlar verme yeteneği olarak kavramsallaştırılmış ve dijital medya ile gençlerin katılımlı oyunuyla geliştirilmiştir.

Sosyal medyada kimlik oluşumunun bir başka boyutu da sosyolojik bağlamda karşımıza çıkmaktadır. "Elektronik enformasyon ortamında, azınlık topluluklarının hesaba katılmaması, göz ardı edilmesi mümkün değil. Şimdi herkes, herkes hakkında gereğinden çok şey bilmektedir. Yeni hayatımız, bu yeni yaşam ortamımız kenarda 


\section{Ali Murat KIRIK, Kenan BÖLÜKBAŞ, Gönül CENGiz, "Sosyal Medya Bağlamında Dijital Vatandaşlk: TRT İstanbul Radyosu Prodüktörleri Üzerinden Bir Değerlendirme” Mavi Atlas, 7(2)/2019: 1-27}

kalmayıp olan bitene katılmamızı, etrafla ilgilenmemizi zorunlu k1lıyor. Şimdi herkes karşılıklı olarak birbiriyle ilintili, birbirinden sorumludur." (Göksal 1994: 53).

Örneğin; bireyler internet üzerinde kendilerini diledikleri şekilde sunabilmektedir. Özcan'a (2012: 27) göre, özellikle sanal dünyalarda ve sosyal ağlarda; kullanıcılar kendilerini en iyi şekilde ifade eder, diledikleri kimlikleri seçebilirler. Bu durum, bireylerin kendilerini yanlış görmelerine, kendilerini toplumsalın inşa ettiğine değil, eşsiz bireyler olarak yanlış tanımalarına neden olmaktadır (Göksal 1994: 54).

Oluşan çok yönlü ve çok sesli dijital mecrada, ideoloji ve kimlik yansımaları incelendiğinde, bireylerin kendilerini ifade etme ve davranış biçimlerinde farklılıkların açığa çıktığı görülmektedir. Göksal'ın (1994: 54) da ifade ettiği gibi, yeni iletişim teknolojilerinin kullanılmasıyla birlikte, öznenin kendini ifade etme biçimleri de değişim göstermiştir.

Aynı zamanda sosyal medyanın bir bütün olarak kültürümüz üzerinde muazzam bir etkisi vardır. Sosyal medya bizi belirli bilgi kaynaklarına yönlendirerek okuduğumuz, duyduğumuz veya izlediklerimizi tanımlamaktadır. Sosyal ağlar ortak ilgi alanı ve özelliklere dayalı olarak gelişimlerini sağlamakta, diğer taraftan da bizleri dış dünyadaki insanlarla daha az sosyalleşmeye itmektedir. Aynı zamanda radikalleşmeyi harekete geçiren bazı sosyal medya fenomenleri, politik kültürümüzde daha geniş kutuplaşmaya da katkıda bulunmaktadır. Özetle, sosyal medya bizi daha verimli tüketiciler ve daha az etkili vatandaşlar yapmaktadır.

Son zamanlarda siber zorbalık, seks ve diğer psikolojik veya fiziksel tehditler dâhil olmak üzere, çevrim içi yaşamın algılanan tehlikeleri dijital vatandaşlık konusunu yeniden gündeme getirmiştir. Gençlerin sosyal medyadaki aktifliği, dijital vatandaşlığın gelişimini desteklemekle beraber sorumluluklarını da arttırmaktadır.

Dijital medya eş zamanlıdır, insanlar istediği zaman ve istediği yerden birçok bilgiye erişim sağlayabilmektedir. Dijital medya hipodermik iğne görünümünden, kullanıcılara bilgi üzerindeki kontrolde devir teslim imkânı sunmaktadır. Her dijital kullanıcı, hipodermik iğnelerine sahip olabilmektedir. Bu bağlamda dijital vatandaşlar içeriği keşfedebilmekte, karşılaştırabilmekte, tartışabilmekte veya oluşturabilmekte, aynı zamanda seçimlerini / kararlarını şekillendirebilmektedirler. Gençlerin canlı olarak tweetlemeli politik protestodan toplum hizmet projelerine katılmaya kadar çeşitli aktiviteleri çevrim içi gerçekleştirmesi sosyal medyada dijital vatandaşlık bilincinin ne denli önemli olduğunu göstermektedir. Bu çevrim içi aktiviteler aracılığıyla, gençler, topluluklarına yarar sağlayan birleştirici eylemlere (örneğin okul, kasaba, devlet ve hayal 


\section{Ali Murat KIRIK, Kenan BÖLÜKBAŞ, Gönül CENGIZ, "Sosyal Medya Bağlamında Dijital Vatandaşlık: TRT İstanbul Radyosu Prodüktörleri Üzerinden Bir Değerlendirme" Mavi Atlas, 7(2)/2019: 1-27}

edilmiş) katılma konusuna da çok heveslidirler. Bu durum da dijital vatandaşlık için bütünleşik bir sosyal medya yaklaşımına ihtiyaç olduğunu göstermektedir.

Erden'in (2017: 4) de belirttiği gibi, günümüzün değişen yaşam koşulları ile birlikte gelen modernleşme süreci, bireylerin toplum yaşantılarını etkileyecek ölçüde iletişim sürecine farklı anlamlar ve tanımlar katmıştır.

Babacan'a (2011: 72) göre, söz konusu yeni medya döneminde eskiye kıyasla bilginin özgürce dolaşımı ve paylaşımı daha kolay sağlanırken, kullanıcılar aktif biçimde sahip oldukları her şeyi paylaşabilmektedirler. Tek taraflı enforme edilmeden, kendileri bizzat özne olarak gerek haberin kaynağı, gerekse haberin yorumcusu olabilmektedir.

Görüldüğü üzere dijital medya, pratikte sunduğu kullanım kolaylığı nedeniyle dijital dünyaya oldukça hitap eden ve geçmişin 'kitle iletişim araçları' olarak nitelendirilen 'klasik' dünyasını başka bir boyuta taşıyan uygulama alanı olarak karşımıza çıkmaktadır.

Yaşar'a (2009: 743-744) göre sosyal medyanın etkin kullanımı sonucunda; hayatımıza bazı yeni kavramlar eklenirken, var olan bazı kavramlar da dönüşüme uğramıştır. Örneğin; kütüphaneler artık sadece "tuğla ve harç" tan oluşan işletme olmaktan çıkmıştır. İnternet ve web, zaman ve mekân kavramlarını ortadan kaldırarak 7 gün 24 saat bilgi hizmetlerine erişimi mümkün hale getirmiştir. Kütüphane dermeleri ve hizmetleri teknolojik gelişmeler aracılığıyla duvarların dışına taşınmıştır.

Dijital vatandaşlığın sunduğu bu pratik kullanımlarla, bireyler, yani aktif dijital vatandaşlar (zaman ve mekân gözetmeksizin) bilgiye kolaylıkla ulaşabilirler. Böylece dijital vatandaşlar, dijital mecrada etkin bir katılımla söz söyleme yetisine de sahip olurlar.

Tüm bunlara ek olarak sosyal medya alanında; kullanım tercihlerine, kullanım sıklığına, paylaşım içeriklerine ve nedenlerine bağlı olarak bir takım doyum kategorileri oluşturulmuştur.

Buna göre sosyal medya alanı; sosyal etkileşim, bilgi arama bilgiye ulaşma bilgi paylaşma, zaman geçirme, eğlence, rahatlama, düşüncelerin ifadesi ve iletişim, kullanım rahatlığı ve kolaylığı, gözetleme ve gözetim, beğenilme, takdir edilme unsurlarını içermektedir (Üçer 2016: 20).

Dijital vatandaşlık - sosyal medya arasındaki bütünleşik yapının temelinde dijital okuryazarlık bulunmaktadır. Ve bahsi geçen bu boyutların bilinçli kullanımı, hem dijital 


\section{Ali Murat KIRIK, Kenan BÖLÜKBAŞ, Gönül CENGIZ, "Sosyal Medya Bağlamında Dijital}

Vatandaşlık: TRT İstanbul Radyosu Prodüktörleri Üzerinden Bir Değerlendirme”

Mavi Atlas, 7(2)/2019: 1-27

vatandaşlığın hem de medya alanındaki kazanımların sağlanmasında olumlu bir iz birakacaktır.

Kısaca özetlemek gerekirse; açılan pencereler, tıklanan sayfalar, yazılı ve görüntülü ortamlarda paylaşılan enformasyonlar, videolar, resimler, kişiler arasında kurulan ittifaklar, çatışmalar, dedikodular, eleştiriler, kurulan yeni arkadaşlıklar, öfke ve sevinç patlamaları, özgürlük ve hak talepleri, müşteri şikâyetleri ve meydan okumalarla sosyal medyalar gündelik dilin her haliyle kullanıldığı sosyal alanlardır ve bu mecradaki her şey sosyal paylaşıma ya da sosyal mübadeleye açıktır.

\section{TRT İstanbul Radyosu Prodüktörleri Üzerinden Dijital Vatandaşlık Kavramının Değerlendirilmesi}

TRT İstanbul Radyosunda, 2017 yılında göreve yeni başlayan prodüktörler (10 prodüktör) ile yapılan çalışmada, sosyal bilimlerde en sık başvurulan veri toplama yöntemlerinden biri olan görüşme tekniği kullanılarak basit tesadüfi örnekleme yapılmıştır. Görüşme yöntemi türlerinden biri olan standartlaştırılmış açık uçlu görüşme türünden faydalanılarak, prodüktörlere konuyla ilgili dikkatlice yazılmış ve belirli sıraya konulmuş 11 soru yöneltilmiş ve her görüşülen bireye bu sorular aynı tarzda ve sırada sorulmuştur. Araştırma kapsamında toplam 10 prodüktör ile araştırmacı tarafindan hazırlanan standartlaştırılmış açık uçlu görüşme formu (EK-1) kullanılarak görüşme gerçekleştirilmiştir. Araştırma soruları, konu ile ilgili literatür taraması sonucunda elde edilen bilgiler doğrultusunda hazırlanmıştır.

Görüşme formunda yer alan sorular "en sık kullanılan sosyal mecra”, Ribble'nin (2011) dijital vatandaşlık kavramını açıklarken kullandığı dokuz boyutu içerecek şekilde "dijital erişim", “dijital ticaret”, “dijital iletişim", "dijital okuryazarlık”, "dijital etik", "dijital hukuk", “dijital haklar”, "dijital sağlık”, “dijital güvenlik” şeklinde alt temalara ayrılmıştır. Aşağıda temalar bağlamında katılımcıların görüşleri analiz edilmiştir.

TEMA 1: En Sik kullanılan Sosyal Mecra

Katılımcılarımızdan 6'sı Instagram, 2'si Twitter, 1'i Facebook sosyal mecrasını daha aktif kullanmaktadır. H.D isimli katılımcı sosyal medya kullanmamaktadır.

TEMA 2: Dijital Erişim

Prodüktörlere "Önemli toplumsal olay ya da gündelik yaşamda yapıp ettiklerimiz karşısında sosyal medyaya 'dijital erişim' sağlanmasının onlar için ne ifade ettiği ve toplumsal kırılmalarda yönlendirici etkisi olup olmadığı" sorusu sorulmuştur. Katılımcıların hepsi, toplumsal olaylarda dijital erişimin yüksek oranda yönlendirici 


\section{Ali Murat KIRIK, Kenan BÖLÜKBAŞ, Gönül CENGIZ, "Sosyal Medya Bağlamında Dijital Vatandaşlık: TRT İstanbul Radyosu Prodüktörleri Üzerinden Bir Değerlendirme" Mavi Atlas, 7(2)/2019: 1-27}

etkisi olduğunu düşünmektedir. H.S. isimli katılımcı, soruya "Yakın zamanda ülkemizde yaşamış olduğumuz 'Gezi olayları' ve '15 Temmuz Hain Darbe Girişimi’ eylemlerinde de gördügüümüz üzere sosyal medyanın yönlendirmelerini bu konuda gerçek anlamda hissettik." şeklinde cevap vererek dijital erişimin bu noktada ne denli önemli olduğunu vurgulamıştır. Diğer taraftan, katılımcıların bazıları dijital erişimin, tehlikeli bir manipülasyon ve provokasyon aracına da dönüşebileceğinin ve etkili olduğu kadar da kontrol edilmesi ve halkı tahrik noktasına sürüklememesi gerektiğinin altını çizmektedir. E.B isimli katılımcı, sosyal medyaya dijital erişimin olumlu etkileri olduğu gibi olumsuz etkileri de olduğunu "Sosyal medya, birçok örgütün bir araya geldiği ve topluluk oluşturduğu bir hal almıştır. Özellikle Arap Baharı, Gezi Parkı olayları gibi durumlar bunun acı etkisini gözler önüne sermektedir.” şeklinde ifade etmiştir. Katılımcılar, dijital erişimin günlük yaşamın her alanına kolayca ulaşılan, takipçilerin gündelik yaşamlarını ciddi bir biçimde etkileyen ve değiştiren bir boyutu olduğunu da belirtmektedir.

\section{TEMA 3: Dijital Ticaret}

"Dijital ticareti hangi alanlarda kullanıyorsunuz?" sorusuna katılımc1lar; kitap, elektronik cihazlar, giyim, oyuncak, ev gereçleri şeklinde yanıt vermişlerdir. İnternetten alışverişin hem zaman hem de fiyat açısından oldukça avantajlı olduğunu vurgulayan katılımcılar, dijital ticaretle sadece alıcı değil aynı zamanda satıcı konumuna da sahip olabildiklerini belirtmektedirler. "Letgo gibi ikinci el sitelerinden kullanılmayan ürünleri satabileceğimiz satıcı konumuna da geçebiliyoruz." (E.B.). Katılımcılara, sosyal medya fenomenlerinin dijital ticareti etkileyip etkilemediğini sorduk ve sosyal medya fenomenlerinin dijital ticareti önemli ölçüde etkilediğini vurgulayan katılımcılar, bunun yanı sıra fenomenlerin onlar üzerinde olumsuz etki bıraktığını da söylemektedir. "Sosyal medya fenomenlerinin reklamlarının farkındayım ama bu bana biraz ters etki yapıyor. $\mathrm{O}$ tarz bir reklam görmek bende zorlama bir tanıtım faaliyeti algısı yaratıyor. Ancak ürünlerin bilinirliğinin artmasında fenomenlerin büyük etkisi yadsınamaz.” (N.Y).

\section{TEMA 4: Dijital İletişim}

"Sosyal medya hesaplarınızdaki mesajlaşma formlarını aktif olarak kullanıyor musunuz?" sorusuna, bilgiye ulaşmak veya elimizdeki bilgiyi doğrulamak açısından oldukça faydalı olmakla beraber, sosyal medya hesaplarını mesajlaşma anlamında aktif olarak kullandıklarını belirten 6 katılımeı ve kullanmayan 1 katılımcı, dijital iletişimi amacına uygun kullanmanın önemini de vurgulamıştır. Dijital iletişimi "Küresel bir köyde ihtiyacınız olan bir bilgiye anında ulaşmak, bu çağın en ayırt edici vasfını nitelendirdiği için büyük avtantaj" olarak gören M.E.T.'nin aksine O.Y. isimli katılımcı 


\section{Ali Murat KIRIK, Kenan BÖLÜKBAŞ, Gönül CENGIZ, "Sosyal Medya Bağlamında Dijital Vatandaşlık: TRT İstanbul Radyosu Prodüktörleri Üzerinden Bir Değerlendirme” Mavi Atlas, 7(2)/2019: 1-27}

"Maalesef yeni nesil gençleri bu platformları daha çok flört için tercih ettikleri için etik sınırların aşıldığı kanaatindeyim." şeklinde fikir bildirerek dijital mesajlaşmanın amacından saptığını vurgulamıştır.

TEMA 5: Dijital Okuryazarlık

Görüşmeye katılan katılımcıların çoğu, dijital okuryazarlık konusunda herhangi bir eğitim almadıklarını belirtmekte, aynı zamanda dijital okuryazarlık konusuna kavramsal olarak da hâkim olmadıklarını ifade etmektedir. İyi bir dijital okuryazar olma konusunda dijital çağa doğan kuşak, her yönüyle dijital göçmenlerin önündedir. Dijital göçmenlere bakıldığında, sosyal medyayı kullanım şekillerinde dahi yanlışlıklar olduğu anlaşılmaktadır. Yeni gelen kuşağı, “dijital beyinler” olarak tanımlayan U.D, bu kuşağın "büyük avantajlarının yanında, duygu ve ruh eksikliği gibi dezavantajlarının da olabileceğini”" ifade etmektedir.

\section{TEMA 6: Dijital Etik}

"Sosyal medya kullanımında "dijital etik" anlamında nelere dikkat ediyorsunuz?" sorusuna katılımcılar, dijital etik konusuna genel olarak günlük yaşamdaki etik kurallarda olduğu gibi riayet ettiklerini ifade etmişlerdir. "Dijital mecrada etik olmayan bir durumla karşılaştıklarında ne gibi önlemler aldıkları" ile ilgili soruya görüş bildiren katılımcılar, gerektiğinde engelleme ya da şikâyet yöntemine başvurduklarını belirtmişlerdir. Fakat buna rağmen engellemelerin dijital etik konusunda şikâyetlere çözüm getirmediğinin üzerinde durmaktadırlar. T.B.: "Yasaklamaların etkili bir şekilde davranış değişikliği oluşturduğunu düşünmüyorum. Ben engellesem de bir başkası görmeye devam ediyor. Bir hesabı kapatılsa bir yenisini açıp ne yapıyorsalar aynen devam edebiliyorlar." Hatta katılımcılardan H.D., sosyal medyadan uzak durmasının asıl nedeninin bu tür olumsuzluklardan kaynaklandığını belirtmektedir.

TEMA 7: Dijital Hukuk

Sosyal medyanın mutlaka denetlenmesi gerektiğini vurgulayan tüm katılımcılar, dijital hukukun bu mecralardaki hakaretleri, iftiraları ciddi anlamda düzene sokacağına inanmaktadır. E.B: "İnsanların, yazdıkları şeylerin farkında olması gerektiğini düşünüyorum. Nasıl Anayasa'da kişinin hak ve hürriyetleri kanun ile korunuyorsa yine aynı yaptırımların dijital hukuk ile de korunması gerektiğini düşünmekteyim.” Dijital hukuk yaptırımlarının daha güçlü olması gerektiğini belirten T.B., aynı zamanda devletin her yerde olması gerektiği gibi dijital ortamlarda da hak kayıplarının önlenmesini 


\section{Ali Murat KIRIK, Kenan BÖLÜKBAŞ, Gönül CENGIZ, "Sosyal Medya Bağlamında Dijital Vatandaşlık: TRT İstanbul Radyosu Prodüktörleri Üzerinden Bir Değerlendirme” Mavi Atlas, 7(2)/2019: 1-27}

engelleyecek, düşünce özgürlüğünün önüne geçmeyecek bir yerde kendini konumlandırmasının önemini vurgulamaktadır.

\section{TEMA 8: Dijital Haklar}

Katılımcılara dijital haklarını bilip bilmedikleri ve bu kapsamda "dijital sorumluluk" olgusunu sorduk. Görüşleri sorulan tüm katılımcılar, dijital haklar konusunda detaylı bilgiye sahip olmadıklarını ama dijital sorumluluklarının farkında olduklarını ifade etmiştir.

\section{TEMA 9: Dijital Sağlık}

Prodüktörlere "dijital sağlık” problemi ile karşılaşıp karşılaşmadıkları hakkında görüş soruldu. Katılımcılardan sadece U.D. "Kesinlikle yaşadım ve yaşıorum. Telefon kullanımı sebebiyle uzanırken veya dinlenme pozisyonu alırken bel ağrıları yaşıyorum" şeklinde görüş bildirirken, diğer 8 katılımeı bu konuda herhangi bir sorun yaşamadığını belirtmiştir.

TEMA 10: Dijital Güvenlik

Katılımcılara "Dijital güvenliğinize dikkat ediyor musunuz?" sorusunu yönelttik ve katılımcıların “gizlilik” konusu hakkında görüşlerini aldık. Dijital güvenlik konusunda hassas davranan katılımcı prodüktörler, bu konuya özellikle dikkat ettiklerini belirterek tanımadıkları kişilerle bu mecralar üzerinden mümkün olduğunca etkileşime geçmediklerini fakat diğer taraftan bu aldıkları güvenlik önlemlerinin yeteri kadar korunaklı olmadığını da vurgulamaktadır. E.B: "Güvenliğime çok dikkat ettiğim için muhtemelen takipçi sayımda çevremdekilerin haricinde çok kimse olmadığını düşünüyorum. Lakin ben hala bilgilerimin üçüncü kişilerle paylaşılma konusunda korunduğumu düşünmüyorum. Gizlilik; sadece uygulama yapımcısının, kullanıcının daha çok paylaşmasını sağlamak için kullanıma sunduğu bir seçenektir." şeklinde konu ile ilgili görüşünü ifade etmiştir.

\section{Sonuç}

Dijital kimlikler, gerçek dünyadaki kimliklerin siber yansımalarıdır. Gelecekte, bu siber yansımalar belki de gerçek dünyadaki varlıklardan daha önemli hâle gelecektir. Dijital kimlik yansımaları, fiziksel kimlik ve karakterlerin yönetildiği gibi yönetilebilir.

Dijital kimlikler, gerçek hayatların dijital dünyadaki yansımasıdır ancak dijital mecraların kullanımının yoğunlaşması, gerçek kimliğini gizleyen, yok eden ya da asimile eden her türlü tehdit ve sosyolojik baskıdan da uzak tutulmalıdır. 


\section{Ali Murat KIRIK, Kenan BÖLÜKBAŞ, Gönül CENGIZ, "Sosyal Medya Bağlamında Dijital Vatandaşlık: TRT İstanbul Radyosu Prodüktörleri Üzerinden Bir Değerlendirme” Mavi Atlas, 7(2)/2019: 1-27}

İletişim, toplum için ne kadar önemli ise onun günümüz şartlarında kendine bulduğu ifade şekli de o denli önemlidir. Dolayısıyla dijital medyanın aktif kullanıcıları olan dijital vatandaşlar, sosyal medya bağlamında bahsedilen ifade şeklini bulmakta ve oluşan durumlara yön verebilmektedirler. Bunu, "artık uzak kavramının göreli bir hal aldığı hatta olmadığı” bir ortamda yapmaktadır.

Ribble'nin, dijital vatandaşılık kavramını açıklarken bu kavramı dokuz boyutta ele aldığından yukarıda bahsedilmektedir. Bu boyutların her birinin, gerçek yaşamda karşı1lı̆̆ olan kavramların yeniden gözden geçirilmesine neden olacağı, bu yüzden de geleneksel vatandaşlık anlayışının bu yeni dijital vatandaşlık anlayışına evrilmesinin çok önemli olduğu ifade edilmektedir. Nitekim bu başlıklar farklı çalışmalar eşliğinde sayısal olarak arttırilabilmektedir.

Ribble'in ele aldığı boyutlar, sosyal medya bağlamında basit tesadüfi örneklemeye başvurularak TRT İstanbul Radyosunda 2017 yılında göreve yeni başlayan prodüktörler ile yapılan görüşmelerle değerlendirilmiştir. Bu kapsamda 10 tema belirlenmiş ve katılımcılara 11 adet soru sorulmuştur. Yapılan görüşmelerden elde edilen sonuçlara göre, prodüktörlerin dijital vatandaşlık ve boyutları ile ilgili yeteri kadar bilgiye sahip olmadıkları, diğer taraftan sosyal medyadaki vatandaşlık görevlerini sorumlu bir şekilde yerine getirmeye çalıştıkları görülmektedir. Konuyu sosyal medya kapsamında ele aldığımızdan, katılımcıların bu noktada daha aktif ve bilinçli olduğu görülse de dijital vatandaşlık kavramları ile ilgili herhangi bir eğitim almadıkları da dikkat çekmektedir.

Katılımcıların dijital medya konusunda yeteri kadar bilgiye sahip olması oldukça önem arz etmektedir. Dijital dönüşümün yaşandığ 1 çağımızda, teknolojiyi yakından takip etmek, herkes için olduğu gibi prodüktörler açısından da elzemdir. Çünkü yayın içerikleri noktasında prodüktörlerin çok büyük bir etkisi bulunmaktadır. Yaptıkları programlar ile toplumun her kesiminden yüz binlerce dinleyiciye ulaşan prodüktörler, seçmiş oldukları konu ve konuklarla radyoda içerik üretimi konusunda oldukça etkin durumdadırlar. Bu nedenle TRT personeline dönem dönem verilecek olan dijital vatandaşl1k eğitimleri, açıkların kapanması noktasında son derece önemli olduğu düşünülmektedir. Sonuç olarak; dijital vatandaşlık kavramı, toplumsal hayatımıza yeni giren kavramlardan biri olduğu için önümüzdeki yıllarda da araştırılmaya ve yukarıda yer verdiğimizden daha farklı yeni boyutlar da kazanmaya devam edecektir.

\section{Kaynakça}

BABACAN, M.E. HİRA, İ., \& HAŞLAK, İ. (2011). "Sosyal Medya ve Arap Baharı”, Sakarya Üniversitesi, Sosyal Bilimler Enstitüsü Dergisi, 6 (2): 63-92. 
Ali Murat KIRIK, Kenan BÖLÜKBAŞ, Gönül CENGIZ, “Sosyal Medya Bağlamında Dijital

Vatandaşlık: TRT İstanbul Radyosu Prodüktörleri Üzerinden Bir Değerlendirme”

Mavi Atlas, 7(2)/2019: 1-27

ÇUBUKCU, A. \& Ş. BAYZAN (2013). "Türkiye'de dijital vatandaşlık algısı ve bu algıyı internetin bilinçli, güvenli ve etkin kullanımı ile artırma yöntemleri”, Middle Eastern \& African Journal of Educational Research, 5:148-174.

DOMINIQUE, Leydet (2006). Citizenship, Stanford Encyclopedia of Philosophy, Stanford University.

ENGİN, Barış (2011). Yeni Medya ve Sosyal Hareketler, Cesur Yeni Medya, ekitap, der. Mutlu Binark, Işık B. Fidaner, Ankara, Alternatif Bilişim Derneği Yayınları.

Erden, Kübra (2017) "Sosyal Medyanın Sessizleştirme Sistemi Bağlamında Değerlendirilmesi: Üniversite Gençliği Üzerine Alan Çalışması.” (Yayınlanmamış Yüksek Lisans Tezi), Gazi Üniversitesi Sosyal Bilimler Enstitüsü, Ankara.

GLEASON, B., \& S. GILLERN, S (2018). "Digital Citizenship with Social Media Participatory Practices of Teaching and Learning in Secondary Education ",Journal of Educational Technology \& Society (21) : 200-212.

GÖKSAL, Eda Coşar (1994). "Yeni İletişim Teknolojilerinde Kimlik, Söylem ve İdeoloji”, (Yayınlanmış Yüksek Lisans Tezi), İstanbul: Marmara Üniversitesi.

GÖRMEZ, Erhan (2017). "Öğretmenlerin "Dijital Vatandaşlık Ve Alt Boyutları" Hakkındaki Düzeyleri (Van İli Örneği)”, Akademik Bakış Dergisi 60 Mart - Nisan: 5274.

GREENHOW, C., \& B. GLEASON (2012). "Twitteracy: Tweeting as a New Literacy Practice" The Educational Forum, 76(4) : 464- 478.

GÜRGEN, Haluk (2017). İletişim Üzerine, Herkes İçin İletişim, ed. Bayrakdar Deniz ve Özlem Avcı Aksoy UNESCO, Ankara.

HONOHAN, Iseult (2002). Civic Republicanism. Routledge Publication.

HUSSAIIN, G., \& E. SALTMAN (2014). Jihad Trending: A comprehensive analysis of online extremism and how to counter it, ( https://www.quilliamfoundation.org/wp/wp-content/uploads/publications/free/jihadtrending-quilliam-report.pdf)

IIJJA, Vera Ilona (2011). An Analysis of the Concept of Citizenship: Legal, Political and Social Dimensions, Master's Thesis, University of Helsinki.

JONES, L., \& K. MİTCHELL (2015). "Defining and Measuring Youth Digital Citizenship”. New Media\&Society 9 (18) : 2063-2079. 
Ali Murat KIRIK, Kenan BÖLÜKBAŞ, Gönül CENGIZ, “Sosyal Medya Bağlamında Dijital

Vatandaşlık: TRT İstanbul Radyosu Prodüktörleri Üzerinden Bir Değerlendirme”

Mavi Atlas, 7(2)/2019: 1-27

KESER, H., SEMERCI, A., \& L. ÇETINKAYA (2018). “Dijital Vatandaşlıkta Güvenlik, Haklar Ve Sorumluluklar”, Eğitim Teknolojileri Okumaları, The Turkish Online Journal of Educational Technology : 270-281.

KİRTIŞ, K. A., \& F. KARAHAN (2011). “To Be Or Not To Be İn Social Media Arena As The Most Cost-Efficient Marketing Strategy After The Global Recession ", Procedia Social and Behavioral Sciences (24): 260-268.

KOCADAĞ, Tuğba (2012). Öğretmen Adaylarının Dijital Vatandaşlık Düzeylerinin Belirlenmesi, (Yayınlanmış Yüksek Lisans Tezi), Trabzon: Karadeniz Teknik Üniversitesi.

MARSHALL, T.H., \& T.B. BOTTOMORE (1992). Citizenship and Social Class , Pluto Press.

MINJEONG, K., \& C. DONGYEON (2018). "Development of Youth Digital Citizenship Scale and Implication for Educational Setting”, Journal of Educational Technology \& Society (1) 21: 155-171.

ÖZCAN Fethi Feyyaz (2012). Yeni Medya ve Dijital Aktivizm, (Yayınlanmış Yüksek Lisans Tezi), İstanbul: Kadir Has Üniversitesi.

ÖZTÜRK, Mesude Canan (2013). Dijital İletişim Ve Yeni Medya , Anadolu Üniversitesi Açıköğretim Yayını.

PEKER, A., \& Y. EROĞLU (2015). "Ergenlerde Algilanan Sosyal Destek ve Siber Zorbalığa Eğilim Arasındaki İlişkiler: Arkadaştan ve Öğretmenden Algılanan Sosyal Desteğin Aracı Rolü”, Turkish Studies-International Periodical for the Languages, Literature and History of Turkish or Turkic 10 (3): 759-778.

POLAT, İsmail Hakk1 (2016). "Dijital - Siber - Sosyal; Yeni Bir Medyadan Yeni Bir Yaşam Alanına Dönüşüm”,TRT Akademi Dijital Medya Sayısı 1 (2): 410- 424.

REYNOLDS, L. \& R. SCOTT (2016). Digital Citizens: Countering Extremism Online, Magdalen House, London.

SAKALLI, Hilal (2015). Sınıf Öğretmeni Adaylarının Dijital Vatandaşlık Düzeyleri İle Siber Zorbalık Ĕgilimleri Arasındaki İlişkininin İncelenmesi, (Yüksek Lisans Tezi), Aydın: Adnan Menderes Üniversitesi.

SARSAR, Fırat (2017). Dijital Vatandaşlık, Değişen Değerler Ve Yeni Eğitim Paradigması, Ed. Salih Zeki Genç, Ankara. 
Ali Murat KIRIK, Kenan BÖLÜKBAŞ, Gönül CENGIZ, "Sosyal Medya Bağlamında Dijital Vatandaşlık: TRT İstanbul Radyosu Prodüktörleri Üzerinden Bir Değerlendirme”

Mavi Atlas, 7(2)/2019: 1-27

SAYIMER, İdil (2009). Sanal Ortamda Stratejik Halkla İlişkiler Yönetimi, İstanbul: Beta Yayınları.

TAYLAN, A. (2015). Nitel ve Nicel Araştırmalarda Evren ve Örneklem Seçimi ve Sorunlar, İletişim Araştırmalarında Yöntemler (Ed. Besim Yıldırım), : 47-85.

TONTA, Yaşar (2009). "Dijital Yerliler, Sosyal Ağlar ve Kütüphanelerin Geleceği”, Türk Kütüphaneciliği 23 (4) :742-768.

TOPRAK, Ali, BİNARK, Mutlu, YILDIRIM Ayşenur vd. (2009). Toplumsal Paylaşım A ̆ğ Facebook: “Görülüyorum Öyleyse Varım, İstanbul: Kalkedon Yayınları.

ÜÇER, Neda (2016). "Kullanımlar ve Doyumlar Yaklaşımı Bağlamında Gençlerin Sosyal Media Kullanımına Yönelik Niteliksel Bir Araştırma”, Global Media Journal TR Edition, 6 (12): 1-26.

YAYLA, Oğuz Turan (2017). Analogtan Dijitale Iletişim Teknolojilerinin Gelişimi: Sosyal Medya Ve Sosyal Değişim, (Yayımlanmamış Yüksek Lisans Tezi,) İstanbul Ticaret Üniversitesi.

\section{İnternet Kaynakları}

Gürcan, H.İ. (2013). İnternette Medya Okuryazarlığı Yaklaşımı, (http://inettr.org.tr/inetconf16/sunum/inettr11-5.doc; Erişim Tarihi. 10.09.2019.

RİBBLE, M. (2011). “Digital citizenship in schoolsISTE \& Eurospan (London)”, Erişim Tarihi: 05.03.2018, (http://www.iste.org/store/product.aspx?ID=2111 )

"Nine elements of digital citizenship", Erişim Tarihi: 10.03.2018, (http://www.waccglobal.org/articles/nine-elements-of-digital-citizenship ).

(http://www.selcuk.edu.tr/dosyalar/files/074/elektronik_ticaret(1).pdf: 19 ). Erişim tarihi: 26.08.19.

(https://www.bbc.com/turkce/haberler-dunya-43469094 2018, Erişim Tarihi 20.09.2019. 


\section{Ali Murat KIRIK, Kenan BÖLÜKBAŞ, Gönül CENGiz, "Sosyal Medya Bağlamında Dijital Vatandaşlık: TRT İstanbul Radyosu Prodüktörleri Üzerinden Bir Değerlendirme" Mavi Atlas, 7(2)/2019: 1-27}

\section{EK:}

\section{Açık Uçlu Görüșme Formu}

Değerli katılımcı, bu çalışmanın amacı göreve yeni başlayan prodüktörlerin "dijital vatandaşlık ve alt boyutları" hakkındaki düşüncelerini ortaya koyarak, konuyla alakalı yeterlilik düzeylerini tespit etmek ve konuyu sosyal medya bağlamında değerlendirmektir. Bu çalışmada, isim ve soy isimlerinizin sadece baş harfleri kullanılacaktır.

\section{Sorular}

1. Hangi sosyal medya hesaplarını kullanıyorsunuz?

2. $\quad$ En çok kullandığınız, en aktif olduğunuz sosyal medya mecrası hangisi?

3. Dijital vatandaşlığı ve boyutlarını sosyal medya bağlamında incelemeye çalışıyoruz. Biliyorsunuz artık sosyal medyanın gücü yadsınamaz bir gerçek. Dolayısıyla eşit olarak katılımın sağlanabilmesi bu noktada çok önemli. Örneğin, önemli bir toplumsal olay ya da gündelik yaşamda yapıp ettiklerimiz karşısında sosyal medyaya "dijital erişim" sağlanması sizin için ne ifade ediyor? Dijital erişimin özellikle toplumsal kırılmaların yaşandığı zamanlarda yönlendirici bir etkisi var mı sizce?

4. Artık insanlar, satma - satın alma işlemleri için elektronik ortamları kullanmaya başladı. En basiti bir kitap almak, bir dokümana ulaşmak bile artık sanal olarak yapılıyor. Peki, siz “dijital ticaret”i hangi alanlarda kullanıyorsunuz? Bunun yanı sıra örneğin, sosyal medya mecrasında fenomen olarak nitelendirilen isimler reklam arac1 olarak da karşımıza çıkabiliyor. Toplumun kanaat önderleri olarak da benimsenen bu fenomenlerin dijital ticareti etkilediğini düşünüyor musunuz?

5. İletişim teknolojik gelişmelerle boyut değiştirdi. Ve birçok alanda olduğu bilgi sanal mecraya taşındı. Anlık mesajlaşmalar, e-posta, cep telefonları derken sosyal medya hesaplarında da, paylaşımlara yapılan yorumlarla ve özel mesajlaşma formları ile "dijital iletişim" mümkün hâle geldi. Sosyal medya hesaplarınızda bu mesajlaşma formlarını aktif olarak kullanıyor musunuz? Tanımadığınız insanlara ulaşma noktasında ya da tanımadığınız insanların size ulaşması noktasında "dijital iletişimi” bir dezavantaj ya da avantaj olarak görüyor musunuz?

6. Dijital çağa doğan bir kuşak var artık. Sizce bu kuşak "dijital okuryazarlık" bağlamında ne kadar bilinçli? Ve bu kuşağı "dijital okuryazarlık” noktasında, teknolojiye 


\section{Ali Murat KIRIK, Kenan BÖLÜKBAŞ, Gönül CENGIZ, "Sosyal Medya Bağlamında Dijital Vatandaşlık: TRT İstanbul Radyosu Prodüktörleri Üzerinden Bir Değerlendirme" Mavi Atlas, 7(2)/2019: 1-27}

daha yabancı olan dijital göçmenlerle karşılaştırmamız gerekse bu konuda neler söylersiniz? Kendinizi bu noktada nerede görüyorsunuz?

7. Sosyal medyayı doğru ve etik kullanım noktasında "dijital okuryazarlık" ne kadar etkilidir?

8. Biliyorsunuz sosyal medya izole bir yapıya sahip. Ve insanlar bir kişinin yüzüne söyleyemeyeceği şeyleri bu izole yapı sayesinde rahatlıkla sanal ortama taşıyabiliyorlar. "Dijital etik" kavramının bu anlamda dijital okuryazarlıkla da ilintili olduğunu söyleyebilir miyiz?

9. Dijital mecrada etik olmayan bir durumla karşılaştı̆̆ınızda ne gibi önlemler alıyorsunuz? Engelleme veya teknolojik anlamda yasaklar koyma gibi çözümlerin sosyal medyada dijital etiği sağlamada nitelikli bir çözüm olduğunu düşünüyor musunuz?

10. Peki, aktif bir sosyal medya kullanıcısı olarak paylaştığınız içeriklerin, görsellerin bir sorumluluğu olduğunu, kanuni bir yaptırım altına alındığını biliyorsunuz. Bu anlamda "dijital hukuk" kavramının özgürlükleri sınırlandırdığını düşünür müsünüz? Ya da sosyal medyada devlet elinin olmasını olumlu mu karşılarsınız?

11. Vatandaşlar dijital mecrada fikir beyan etmek, tartışmalara katılmak, gruplar kurmak hakkına sahiptir fakat her hak gibi dijital hakların da bir sorumluluğu bulunmaktadır. Bu noktada dijital bir vatandaş olarak "dijital haklarınızı" yeterince kullandığınızı düşünüyor musunuz? Ve dijital haklarınızı "dijital sorumluluk" olgusunu göz önüne alarak mı kullanıyorsunuz?

12. İnsanlar artık vakitlerinin büyük bölümünü sosyal medyada, bilgisayar karşısında ya da mobil olarak cep telefonlarıyla geçirmekte. Fakat birçok durumda olduğu gibi sosyal medyanın da gereğinden fazla kullanımı bir takım sağlık sorunlarına neden olmaktadır. A-sosyal yaşam, içe kapanıklık, fiziksel bozukluklar, göz kuruluğu gibi. Bu anlamda siz, herhangi bir "dijital sağlık” problemi ile karşılaştınız mı?

13. Dijital güvenliğinize dikkat ediyor musunuz? Sosyal medya hesaplarınızda güvenliğinizi sağlamak için "gizlilik” konusunda neler yapıyorsunuz, ne gibi önlemler aliyorsunuz? 